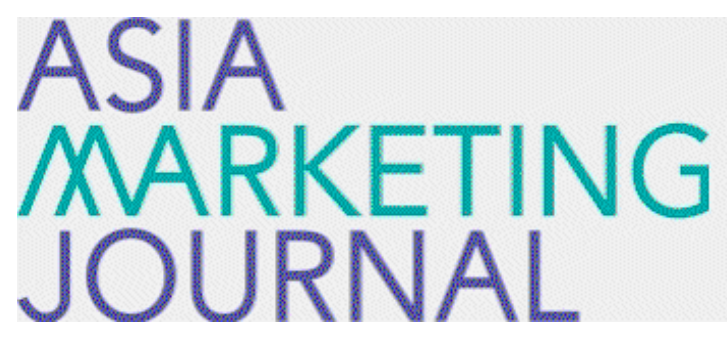

ASIA MARKETING JOURNAL

Volume 8 | Issue 3

Article 6

$10-30-2006$

\title{
통합적 브랜드 전략과 창의적 미디어 솔루션을 조화시킨 마케팅 커 뮤니케이션 선도기업
}

Eun Ju Lee

Chang Jo Yoo

Sang Lin Han

Follow this and additional works at: https://amj.kma.re.kr/journal

Part of the Marketing Commons

\section{Recommended Citation}

Lee, Eun Ju; Yoo, Chang Jo; and Han, Sang Lin (2006) "톨합적 브랜드 전략과 창의적 미디어 솔루션을 조화 시킨 마케팅 커뮤니케이션 선도기업," Asia Marketing Journal: Vol. 8 : Iss. 3 , Article 6.

Available at: https://doi.org/10.53728/2765-6500.1175

This Article is brought to you for free and open access by Asia Marketing Journal. It has been accepted for inclusion in Asia Marketing Journal by an authorized editor of Asia Marketing Journal. 


\section{통합적 브랜드 전략과 창의적 미디어 솔루션을 조화시킨 마케팅 커뮤니케이션 선도기업 - 제일기획*}

Cheil Communications: Empowering Brands with Total Strategic Planning and Creative Media Solutions

이 은 주(Lee, Eun-Ju)**

유 창 조(Yoo, Chang Jo)***

한 상 린(Han, Sang Lin)****

창사 이래 한국 광고 업계를 선도해 온 제일기획의 성공 전략은 크게 다음의 세 가지로 정리될 수 있다. 첫째는 클라이언트의 브랜드 자산을 극대화하는 통합적 브랜드 관리 시스템, 둘째는 창의적 완 성도를 극대화하는 크리에이티브 전략, 그리고 셋째는 체계적인 소비자 조사 결과를 바탕으로 한 과 학적 미디어 전략이다. 본 사례에서는 제일기획의 성공 전략을 다각적으로 검토해 보고, 변화하는 환 경 속에서 지속적인 경쟁력 강화를 통해 클라이언트에게 높은 고객 가치를 창출해 온 제일기획의 노 력상을 조명해 본다.

핵심개념: 제일기획, 통합적 브랜드 관리, 크리에이티브 전략, 미디어 전략, 소비자 조사

\section{I. 서 론}

21세기 기술 환경의 급속한 발전을 바탕으로 전 세계가 빠르게 지식 정보 기반의 미디어 사 회로 변모해 나가고 있다. 디지털 미디어의 확 산이 급속화되면서 기업이 소비자에게 제품 정
보를 전달하던 기존의 일방적 광고보다는 소비 자 간 $(\mathrm{C} 2 \mathrm{C})$, 기업 간 $(\mathrm{B} 2 \mathrm{~B})$ 의 혹은 소비자와 기업 간(B2C)의 쌍방향 커뮤니케이션이 활성 화되어 전반적으로 개인이 받게 되는 정보의 양이 급증하고 있으며, 끊임없이 쏟아지는 광고 세례로 인해 광고에 대한 대중의 태도가 관심 보다는 무관심으로, 호의보다는 회의적 방향으

\footnotetext{
* 본 사례를 작성하는데 있어 도움을 주신 제일기획 관계자분(박재항 국장, 한규훈 박사)께 심심한 감사를 표합니다.

** 중앙대학교 경영학과 조교수(elee9@cau.ac.kr)

** 동국대학교 경영학과 교수(cjyoo@dgu.ac.kr)

*** 한양대학교 경영학과 교수(slhan@hanyang.ac.kr)
} 
로 흘러가는 추세이다. 이와 더불어 소득 수준 과 삶의 질에 대한 기대가 높아지면서 보다 섬 세하고 다양한 제품과 서비스에 대한 소비자들 의 정보적, 감성적 욕구가 증가하고 있다. 따라 서 더 이상 단발적인 판매성 광고의 시행만으 로 소비자의 궁극적인 태도 변화와 구매 행동 을 유도한다고 보기에는 어려움이 있으며, 광고 커뮤니케이션 자체도 보다 세련되고 섬세하게 소비자의 심층 심리를 이해하면서 궁극적으로 는 소비자의 마인드에 각인될 수 있는 강력한 브랜드를 구축해 나가는 장기적인 브랜드 전략 으로 풀어나가야 하는 실정이다.

국내외적으로 소비자의 관심을 끌기 위한 보 이지 않는 전쟁이 이루어지는 경쟁적 미디어 시장, 또한 외국계 광고 대행사들이 국내 시장 에 대한 시장 공략을 가속화하고 있는 어려운 시점에도 제일 기획은 다각적 마케팅 커뮤니케
이션 전략을 지속적이고 성공적으로 구사함으 로써 한국 광고계 제 일인자의 자리를 확고히 지켜왔다. 본 사례에서는 시장을 선도하고 수요 를 창출하는 제일기획의 다각적 마케팅 커뮤니 케이션 전략을 살펴보고, 변화하는 환경 속에서 지속적인 경쟁력 강화를 통해 글로벌 일류 기 업이 되기 위한 노력상을 소개하고자 한다.

\section{II. 제일기획의 연혁}

\section{1 제일기획의 역사}

제일기획은 1973 년 창립시 자본금 5 천만원, 총 직원 33명으로 시작하여 2005년 국내외 연 계 취급고 1 조 7 천억원 가량을 달성한 국내 최

$<$ 그림 $1>$ 제일 기획의 성장 추이

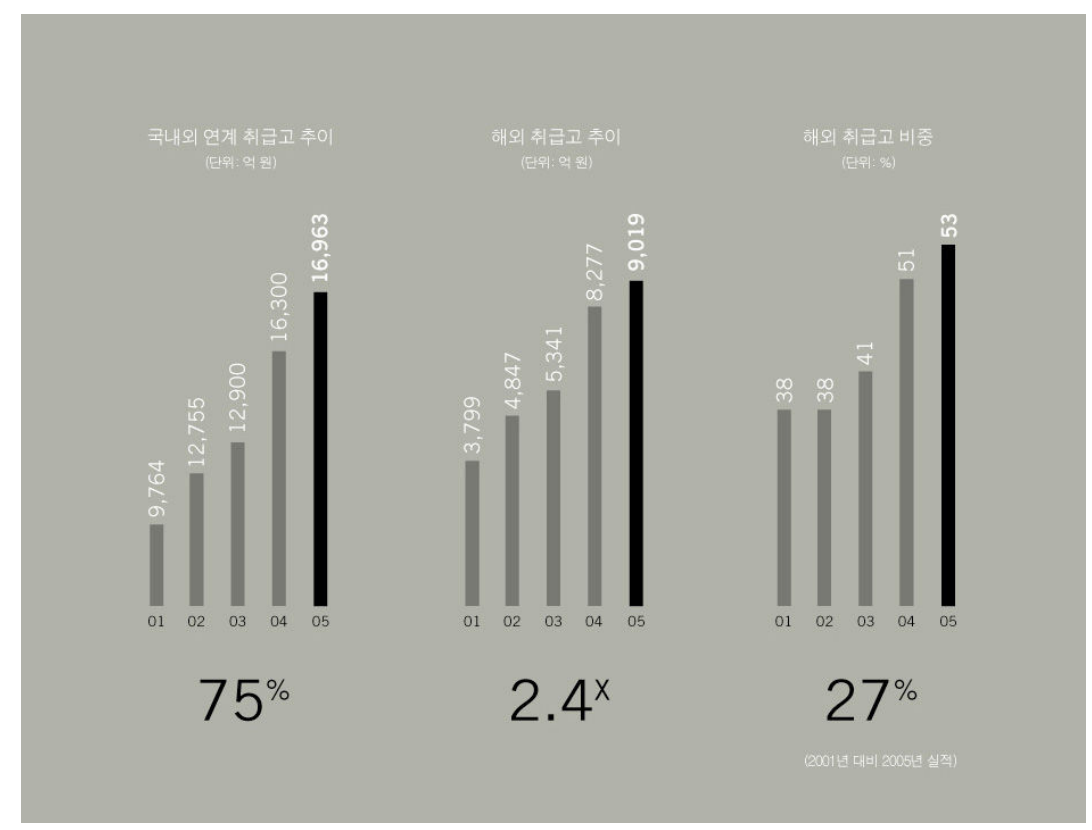


고의 광고 대행사(advertising agency)로 성장 하였다. 2005년 매출액은 5,436억원으로 경상이 익이 716 억원에 이르고 있다. 또한 해외 취급고 의 비중이 전체 취급고의 $53 \%$ 를 넘고 있으며,
국내 취급고보다 해외 취급고의 비중이 점점 증가하는 경향을 나타내고 있다. 제일기획은 국 내 광고 대행사 중 가장 높은 시장 점유율을 소유하고 있을 뿐 아니라, 근래에 들어서는 2 위

\section{<표 1> 제일기획의 주요 연혁}

\begin{tabular}{|c|c|}
\hline 1973 & (주)제일기획 창립 (자본금 5천만원, 2국 10부 33명 직원) \\
\hline 1977 & 취급고 100 억 돌파 (세계 97위 기록) \\
\hline 1979 & 창립 5주년 기념, 업계 최초로 '광고연감’ 발간 \\
\hline 1984 & 매체업무 과학화 및 체계화를 위해 국내매체자료집 ‘미디어가이드' 발간 \\
\hline 1987 & $\begin{array}{l}\text { ‘인간과 호흡하는 기술, 휴먼테크’ 광고로 Clio Awards에서 국내최초로 본상 수상 } \\
\text { 취급고 } 1000 \text { 억 돌파 (광고주 } 37 \text { 개사 개발) }\end{array}$ \\
\hline 1988 & 해외 경쟁력 강화 및 삼성전자 마케팅 지원을 위한 일본내 동경사무소 개설 \\
\hline 1989 & 광고시장 개방에 따라 합작 자회사 (주)제일보젤(제일기획 $70 \%$, 美 보젤 30\%) 설립 \\
\hline 1990 & $\begin{array}{l}\text { 종합 커뮤니케이션 회사로 거듭나기 위해 新 CI 및 기업슬로건('No.1 in Strategy, No.1 in } \\
\text { Creative') 제정 }\end{array}$ \\
\hline 1991 & $\begin{array}{l}\text { 세계최고 권위의 칸느 광고제에서 ‘음주운전 방지캠페인’으로 국내최초 은사자장 수상 } \\
\text { 마케팅능력 강화를 위해 국내 최초로 부설 마케팅연구소 설립 }\end{array}$ \\
\hline 1992 & 뉴욕에 현지법인 Cheil Communication America Inc. 설립, 해외시장 본격 진출 \\
\hline 1994 & $\begin{array}{l}\text { 삼성전자 노비타, 바이오TV, 삼성그룹 기업PR 세계일류시리즈 등으로 국내 소 광고상에 걸쳐 } \\
\text { 대상 석권 }\end{array}$ \\
\hline 1997 & $\begin{array}{l}\text { 통합 업무정보시스템 CATS 개발 및 도입으로 서비스와 업무효율성 향상 } \\
\text { 삼성전자 와이드 TV광고로 칸느 광고제 금사자상 수상 }\end{array}$ \\
\hline 1998 & $\begin{array}{l}\text { 국내 광고회사 최초로 증권거래소 주식상장 } \\
\text { 나가노 동계올림픽 Top 마케팅 전개 }\end{array}$ \\
\hline 1999 & $\begin{array}{l}\text { 인사제도 개선: 성과중심 인사, } \mathrm{CD} \text { 지명제, } \mathrm{AP} \text { 제 도입 } \\
\text { 사내 지식관리시스템 ‘COOK' 오픈 }\end{array}$ \\
\hline 2000 & $\begin{array}{l}\text { 마케팅연구소를 브랜드컨설팅연구소로 확대 개편 } \\
\text { 시드니 하계올림픽 Top 마케팅 } \\
\text { 합작 자회사 (주하쿠호도제일 설립 (일본계 대형 광고주 유치 기대) }\end{array}$ \\
\hline 2002 & $\begin{array}{l}\text { 한-일 월드컵 개막식 행사 개최 } \\
\text { 우리나라 광고 역사상 최초로 취급고 1조원 돌파 및 세계 } 20 \text { 위권 진입 }\end{array}$ \\
\hline 2003 & $\begin{array}{l}\text { 글로벌시대를 위한 新가치체계 제정 및 발표 - 'Creative Intelligence' } \\
\text { (Creativity, Humanity, Enthusiasm, Intelligence, Leadership) }\end{array}$ \\
\hline 2004 & $\begin{array}{l}\text { 아테네올림픽 파트너 삼성전자의 마케팅활동 지원 } \\
\text { 대한민국 광고대상 TV부문 금, 은, 동상 석권 }\end{array}$ \\
\hline 2005 & $\begin{array}{l}\text { 삼성전자의 유럽 명문 축구클럽 첼시(Chelsea) 후원 마케팅 수행 } \\
\text { Institutional Investor 선정, 방송미디어산업부문 '아시아 최우수 IR기업’ 수상 }\end{array}$ \\
\hline
\end{tabular}


대행사와의 시장 격차가 점점 증가하는 추세를 보이고 있어, 한국 광고업계 일인자로서의 자리 매김을 더욱 확고히 해 나가고 있는 것으로 추 정된다 (<그림 1> 참조). <표 1>에서는 제일기획 의 주요 연혁을 간략히 소개하였다.

\section{2 제일기획의 경영 이념}

제일기획은 2003년 30주년을 맞음과 동시에 글로벌시대를 위한 신가치 체계를 발표하였 다. 제일기획이 추구하는 슬로건은 "Creative Intelligence"로서, 이는 창의성(Creativity- 클라 이언트에게 새로운 커뮤니케이션의 솔루션을 제공하기 위해 창의적으로 생각하고 행동함), 인간미(Humanity-세상에 보다 따뜻한 시선이 넘치도록 인간미 넘치는 커뮤니케이션 지향함), 열정(Enthusiasm-뜨거운 열정의 소유자), 지성 (Intelligence-전략적으로 사고하고 냉철하게 판 단), 주인 의식 (Leadership -클라이언트의 성 장을 주도하는 견인차적 역할 담당)을 표방하 는 것이다. 다시 말해 "창의력과 논리력의 조화 를 통해 독특한 아이디어와 차별화된 전략으로 고객의 기대를 뛰어넘는 만족"을 창출하고자 하는 것이 제일기획의 경영이념이다.

\section{III. 제일기획의 성공전략}

제일기획의 성공 전략은 크게 다음의 세 가지 로 정리될 수 있다. 첫번째는 브랜드 가치의 극 대화 전략이다. 명확한 브랜드 컨셉 수립 및 장 기적인 브랜드 관리 전략을 구사하면서 클라이
언트의 브랜드 자산을 극대화하고자 끓임없이 경주하였다. 두번째 전략은 창의적 완성도를 극 대화하는 크리에이티브 전략이다. 제일기획은 광고계의 선진 이론과 제작 기법을 발빠르게 도입하기 위한 다양한 교육 프로그램을 시도하 면서 보다 완성도가 높은 아트워크를 제작, 소 비자의 감성에 소구할 수 있는 광고 제작을 위 해 끊임없이 노력하고 있다. 세번째 전략은 미 디어 전략으로서, 국내 최초로 광고량 조사 및 광고 관련 통계 자료를 체계적으로 수집하고 전산화하였으며, 과학적인 미디어 조사 결과를 바탕으로 한 미디어 전략을 실행함으로써 국내 광고계가 선진화 되는 데 한 몫 기여하였다. 다 음 장에서는 제일기획의 성장 원동력이 된 이 세 가지 전략을 구체적으로 살펴보고자 한다.

\section{1 파워 브랜드 창출 전략}

브랜드는 과거에는 자사 제품을 다른 제품과 구별해 내기 위한 이름, 명칭으로서 사용되었지 만, 최근에는 기업의 자산으로 보는 시각이 우 세하다 (Aaker 1991). 다시 말해 브랜드 자산 (brand equity)이란 무형의 자산이지만 기업의 가치를 판단하는데 있어 가장 중요한 재무적 성과 지표로 볼 수 있다. 제일기획은 클라이언 트 즉 광고주의 성장을 통해 발전한다는 믿음 아래 클라이언트의 브랜드 가치를 극대화하는 파워 브랜드 창출 전략을 모색하고 있다. 이를 위해 제일기획은 내부(in-house) 브랜드 마케팅 연구소를 개설하고 주요 광고주 별로 전담 조 직인 Account Planning(AP) 시스템으로 조직 을 재정비하여 각 클라이언트 별로 통합적인 브랜드 관리 모델을 장기적으로 제시하였다. 
제일기획 브랜드 전략의 가장 큰 장점은 과학 적 소비자 조사에 근거하여 지속 가능한 (sustainable) 파워 브랜드를 구축하는 장기적 이고 통합적 전략을 제공한다는 점이다. 제일기 획이 제공하는 토탈 브랜드 컨설팅의 전략적 프레임워크에는 Cheil B-Master, Value-Up 모 델, KISS (Key to Impact Sales Spots) 등이 포함된다. 제일 브랜드 마스터(Cheil B-Master) (<그림 2> 참조)는 브랜드 자산을 직접적으로 정의하여 측정함으로써 브랜드 자산을 통합적 으로 관리하는 것이 가능하게 한 통합적 브랜 드 관리 시스템이다. 브랜드의 탄생에서부터 브
랜드 성장 진단 및 평가, 브랜드 포지셔닝 기획 및 전략화 프로그램 실행, 그리고 궁극적으로 파워 브랜드로 육성시킬 때까지 광고주의 브랜 드 자산을 장기적으로 관리해주는 시스템으로 서 그 하부에 다양한 개념 모델들을 포괄한다 (<표 $2>$ 참조).

제일기획의 B-Master 시스템 중 브랜드 밸류 업(Value-Up) 모델은 고객 관점에서 브랜드 자산을 정량화하여 이를 전략적으로 실무에 적 용 가능케 한 모델이다(하영원 등 2003). 브랜 드 밸류 업 모델에서는 고객 중심의 관점에서 브랜드 자산의 형성 원천과 시장 성과(brand

\section{<그림 2> 제일기획의 브랜드 전략 시스템 B-Master}

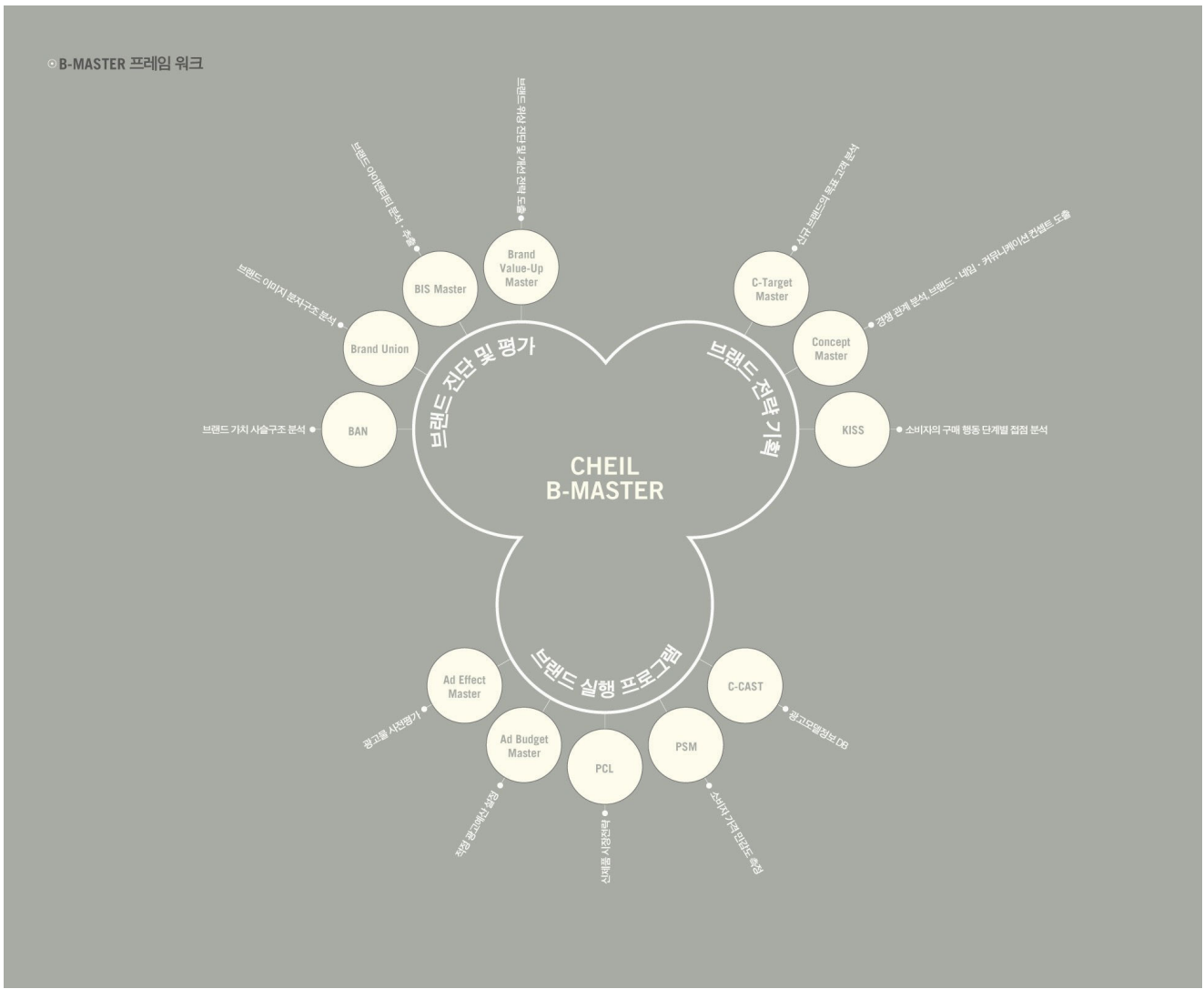


<표 2> 제일기획 B-Master의 상세 설명

\begin{tabular}{|c|c|c|}
\hline 단계 & 모델 & 설명 \\
\hline \multirow[t]{4}{*}{ 브랜드 진단 및 평가 } & Brand Value-Up Master & 브랜드 위상 진단 및 개선 전략 도출 설명 \\
\hline & BIS Master & 브랜드 원칙과 체계를 구축하기 위한 모델 \\
\hline & Brand Union & 브랜드 이미지 분자 구조 분석 \\
\hline & BAN & 브랜드 연상 망 \\
\hline \multirow[t]{2}{*}{ 브랜드 전략 기획 } & C-Target Master & 브랜드 목표 고객에 대한 분석 모델 \\
\hline & Concept Master & $\begin{array}{l}\text { 소비자 내면적 속성과 심층 심리를 파악하여 최적의 브랜드 컨셉 } \\
\text { 도출 모델 }\end{array}$ \\
\hline \multirow[t]{5}{*}{ 브랜드 실행 프로그램 } & Ad Effect Master & $\begin{array}{l}\text { 광고물 사전 사후 평가하여 광고의 개선 방향을 파악하고 지속적 } \\
\text { 으로 광고효과를 관리하기 위한 모델 }\end{array}$ \\
\hline & Ad Budget Master & 브랜드 커뮤니케이션을 위한 최적의 광고 예산 설정 모델 \\
\hline & $\begin{array}{l}\text { PSM (Price Sensitivity } \\
\text { Measurement) }\end{array}$ & $\begin{array}{l}\text { 소비자에게 가장 저항감이 없는 가격을 찾아내는 방법으로 전략 } \\
\text { 적 활용이 높은 가격 설정 모델 }\end{array}$ \\
\hline & $\begin{array}{l}\text { PCL (Product Clinic } \\
\text { Laboratory) }\end{array}$ & $\begin{array}{l}\text { 소비자가 실제 구매 과정에서 거치는 광고, 연상, 접촉, 사용의 } \\
\text { 각 단계별로 신제품을 평가하고 출시 후의 시장 전망과 대응전략 } \\
\text { 도출이 가능한 신제품 마케팅 모델 }\end{array}$ \\
\hline & C-CAST & $\begin{array}{l}\text { 광고 모델의 매력도와 신뢰도 이미지 등을 객관적으로 측정, 광 } \\
\text { 고의 목적과 이미지에 맞는 모델을 과학적으로 선정하기 위한 광 } \\
\text { 고모델 정보의 데이타베이스 }\end{array}$ \\
\hline
\end{tabular}

performance)를 구분하고 있다. 브랜드 자산의 형성 원천의 첫번째 요소로는 인지 파워 (awareness power), 두번째 요소로는 지각된 품질과(perceived quality) 기능 파워(functional power), 세번째 요소로는 이미지/연상(image/ association) 등의 이미지 파워(image power)를 규명하고, 시장 성과로는 브랜드 로열티, 구매 의향, 상대적 지각 가치를 포함시켰다. 브랜드 밸류 업 모델에서는 인지 파워, 기능성 파워, 이미지 파워의 세 부분을 종합하여 브랜드 성 과를 100 점 만점의 표준화 지수로 구하게 되므 로 경쟁 브랜드 간의 항목별 전략적 비교가 용 이하다. 실제로 제일기획은 브랜드 밸류 업 모
델을 사용하여 전자, 통신, 아파트 등 가장 치 열한 경쟁 관계에 있는 업종에서 경쟁 기업 간 의 브랜드 자산의 세밀한 차이를 분석해 낼 수 있었다. 또한 브랜드 밸류 업 모델을 사용함에 있어 라면 등 구매 빈도가 높은 품목뿐 아니라 보험, 은행, 카드, 증권과 같은 금융, 놀이 동산 등 여가 산업 분야를 포함한 총 21 개 업종에 대한 심층적인 분석을 실시함으로써 국내에서 는 가장 포괄적인 브랜드 자산 데이터베이스를 갖추게 되었다.

2003년 개발된 제일 브랜드 유니온 모델(Cheil Brand Union Model)은 기존의 브랜드 자산 혹 은 브랜드 아이덴티티 모델의 이차원적이고 계 
층적인 구조를 개선하였다. 소비자 내면에 실재 하는 브랜드에 대한 생각 관념 감성 이미지 경 험 등이 보다 유기적으로 네트워크로 연결되어 있다는 것에 착안하였고, 3 차원 분자구조라는 시각적인 형태로 소비자 브랜드 스키마 (schema)를 구성하는 방법이다. 브랜드 유니온 모델에서 개별 분자 구조는 분자핵, 원자, 연결 선으로 구성된다. 분자핵은 분석의 핵심 대상 브랜드이며 때로는 모회사 브랜드 혹은 독점 기업 브랜드, 개별 브랜드 등 다양한 수준으로 정의될 수 있다(<그림 3> 참조). 브랜드 유니온 모델에서 분자핵은 하나이지만, 분자의 구성 원 자는 무수히 많을 수 있으며, 제품에 대한 이미 지, 카테고리, 사용자, 모델, 속성 등 브랜드에 서 연상되는 모든 개념이 원자가 될 수 있다. 예를 들어, 애니콜하면 소비자는 '휴대폰(제품 카테고리), 삼성전자(모회사), 이효리(광고모 델), 싸이언(경쟁회사)' 등 다양한 연상을 할
수 있는데 이런 것들이 모두 원자가 될 수 있 다. 원자의 크기를 크게 혹은 작게 함으로써 원 자가 분자 핵에 미치는 영향력을 가시화시킬 수 있다. 원자와 원자를 연결하는 선은 원자들 간의 연상 관계를 나타내며, 원자 간의 혹은 원 자에서 핵으로 이르는 연결선들이 모여 총체적 인 관계 네트워크가 구성된다. 또한 선의 강도 를 조정하여, 상관관계가 강할수록 두꺼운 선으 로, 약할수록 가는 선으로 연결하면 개념 간의 연결 강도가 표시될 수 있다. 원자 간의 위치는 직접 연결, 1 차 연결, 2 차 혹은 $3,4,5$ 차 연결 등으로 확장되는데, 서로간의 좌표가 가까울수 록 보다 직접적인 연상 관계를 가지는 것이다. 결론적으로 브랜드 유니온 모델의 연결망은 기 존의 이차원의 계층적 브랜드 모델에서 진일보 된 형태로써, 모든 개별 원자 간의 직 간접적 연결이 가능한 다차원의 네트워크이다. ${ }^{1)}$

브랜드 유니온 모델의 장점은 우선 소비자들

$<$ 그림 3> Cheil Brand Union Model의 기본형태 및 결과물 예시
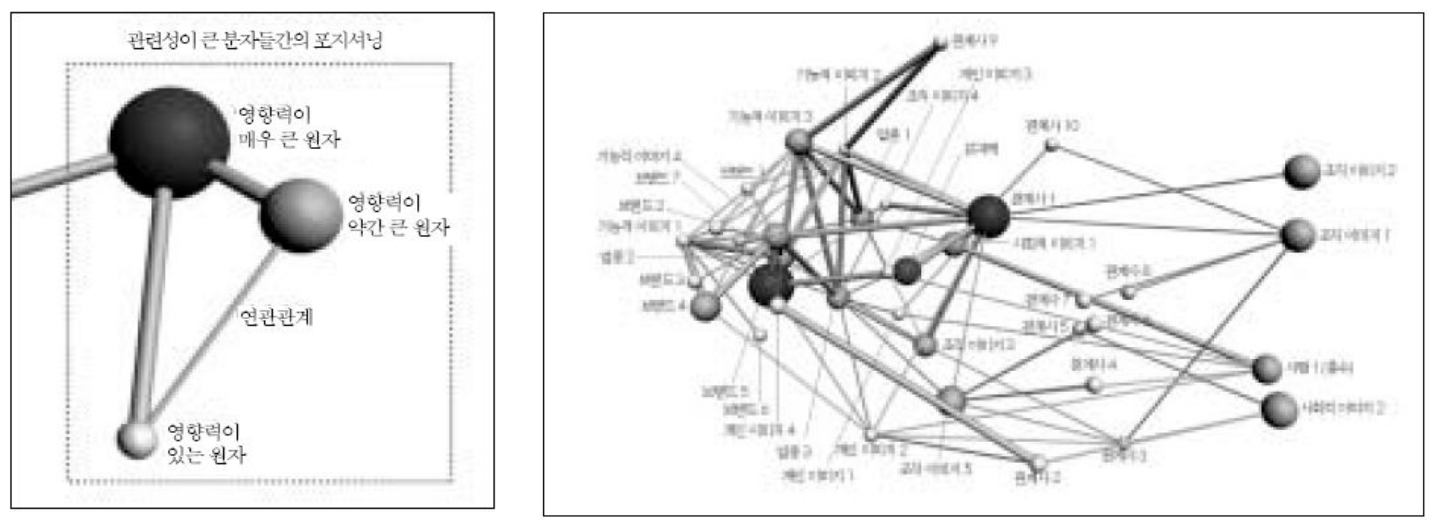

1) 브랜드 유니온 모델의 분자 구조 형성 과정에는 여러 개념 및 기법들이 활용되었다. 원자를 선정함에 있어서 수단-목적 사슬 이론 (means-end chain)개념이 사용되었으며, 래더링(laddering) 기법을 이용하여 속성-혜택-가치에 이르는 모든 래더(ladder) 단계들을 형상화하여 구조화시켰다. 설문지를 활용한 소비자 정량 조사와 Q-sorting 기법을 활용하여 각 원 자들이 분자핵에 미치는 영향력을 평가한 후 분자의 색상과 크기를 정하게 된다. 원자들 간의 상호 연관성 및 영향력은 연관성 행렬(matrix)와 다차원척도(multi-dimensional scaling)를 활용해 좌표를 구하고 최종적으로 시각화한다. 
이 바라보는 브랜드 이미지를 하위 브랜드, 제 품, 이미지, 관련된 사람, 일련의 사건 등 모든 분야에 걸쳐 보다 총체적이고 유기적인 관계망 으로 제시했다는 것이다. 두번째로 브랜드 유니 온 모델을 사용하면 분자핵의 이미지 형성에 가장 중요한 영향을 미치는 메인 드라이버를 알아낼 수 있고, 또한 메인 드라이버들이 각각 어떤 이미지 속성에 의해 영향을 받는지가 밝혀 지게 된다. 셋째로 목적 수단 사슬을 사용할 경우 소비자들의 가치(values)와 혜택(benefits), 그 리고 혜택의 근거가 되는 제품 속성(attribute) 을 밝혀내게 되므로, 브랜드 이미지 측정 및 관 리에 도움이 될 수 있다. 또한 브랜드 이미지 및 자산 관리를 위한 전략적인 의사 결정의 도 구가 될 수 있으며, 향후 소비자 조사 및 광고 커뮤니케이션 시에도 브랜드 컨셉이 이로부터 직접적으로 도출 가능하다. 더나아가 브랜드 유 니온 모델 조사를 종단적으로 실시할 경우 클 라이언트의 브랜드 이미지가 어떻게 변천되는 지 역사적으로 추적(tracking)할 수 있어 장기 적인 브랜드 조망이 가능하다.

브랜드 유니온 모델이 언어 텍스트를 바탕으 로 구성된다면 2006년 제일기획이 개발한 HEART(High Emotional Association Research Tool)모델은 브랜드의 컨셉과 이미지를 시각적 으로 구현하는 이미지 데이터베이스이다. HEART 의 개발은 소비자의 브랜드 이미지는 언어적으 로만 아니라, 공감감적으로 구성된다는 점에서 착안되었다. HEART 는 시각적 자료인 사진이 나 포토 메일을 활용한 새로운 정성적 연구 조 사(qualitative research)를 활용하는 브랜드 모 델로서, 크리에이티브 아이디어 발상 및 매체 사용에 있어 구체적인 시사점들을 시각적으로
제시할 수 있을 것으로 기대되고 있다.

제일기획이 2005년 개발한 KISS (Key to Impact Sales Spot)는 소비자와 브랜드의 접점 을 밝히고, 이를 사용해 마케팅 커뮤니케이션 효율을 높이는 전략적 기초 자료이다. 제일기획 이 전국적으로 실시하는 소비자 데이터베이스 인 ACR(Annual Consumer Research)과 연계 하여 특정 타겟의 브랜드 접점 분석이 가능하 다는 점이 이 모델의 강점이다. KISS의 첫번째 분류는 우선 4 대 매체 (TV, 라디오, 신문, 잡 지)인 ATL(above the line) 미디어와 기타 세 일즈 프로모션과 이벤트로 대표되는 BTL (below the line) 미디어의 두 개의 커뮤니케이 션 게이트(communication gate: $\mathrm{CG}$ )로 구분된 다. 두번째 분류는 ATL의 광고 한 개 채널과 BTL 영역에서 세일즈 프로모션, 이벤트, PR (public relations), 스페이스, 옥외광고, 스포츠 마케팅, 인터넷/모바일, 고객 관계 관리 (customer relationship management), 심벌, 입소문의 10 개 채널로 구성되어 있는 11 개의 커뮤니케이션 채널 (communication channel: C2)이며, 세번 째 단계에서는 브랜드와 소비자가 실제적으로 만나는 접점인 ATL 영역에서의 다섯 개 접점 과(TV 광고, 라디오 광고, 신문 광고, 잡지 광 고, 케이블 및 위성 $\mathrm{TV}$ 광고), BTL에서 10 개 채널 플러스 45 개의 판매 접점 (sales spot: S2)을 포괄한다. KISS는 소비자 구매 프로세스 를 정보 처리 학습 이론에 근거하여, 인지-이해 -호감-구매-구매후 평가의 다섯 단계로 재구성 하였다. 이를 각각 (1)브랜드 인지 지표인 상기 지수 (2)브랜드 이해 지표인 정보 지수 (3) 브 랜드 호감 지표인 매력 지수 (4) 브랜드 구매 지표인 결정 지수 (5) 구매 후 평가지표인 평 
가 지수의 다섯 가지로 분류하고 있다. 제일 $\mathrm{KISS}$ 분석을 통하여 (1) 각 프로세스 별 광고 의 영향력 분석 (2) 목표 고객 분석 (3) 경쟁 분석 (4) 업종별 순위 분석 (5) 효율성 분석 (6) 전략 분석을 수행할 수 있다. KISS의 업그 레이드 모델인 KISS PRISM에서는 정량조사 $\mathrm{KISS}$ 를 바탕으로 최적 소비자 접점을 도출하 기 위해 ATL, BTL을 망라한 ROI(return on investment)적 접근법의 사용으로 클라이언트 가 마케팅 비용을 보다 효율적으로 사용할 수 있게 하는 광고 예산 설정의 새로운 과학적인 틀을 제공하였다.

제일기획은 1986년부터 전국 소비자 조사 (Annual Consumer Research: ACR)를 지속적 으로 실시하여 소비자 의식과 행동 변화를 종 적으로 추적하는 국내 최대의 소비자 데이터베 이스를 구축하여 왔는데, 이를 바탕으로 보다 과학적이고 체계적인 미디어 소비자 분석이 가 능하다. ACR에는 인구통계학적인 정보는 물론 소비자 라이프스타일, 상품의 이용과 구매 실 태, 매체 접촉 실태 등이 조사되고 있어 특정 타겟 소비자들의 브랜드 접점 분석이 가능하다. 이외에도 제일기획은 광고주의 시장 관련 문제 의 효율적인 해결을 위해 지식 활용 시스템 (Creative Optimizer by Online Knowledge: $\mathrm{COOK})$ 을 통해 각종 지식 뱅크를 구축하는 노 력을 쏟는 등 소비자 이해 및 브랜드 전략 구 축을 위한 실증적 기반을 마련해왔다.

제일기획에서 발간하는 또 다른 보고서는 소 비자 트렌드 분석 리포트 (consumer trend report: CTR)로서, 'P 세대', '와인 세대', '포스 트 디지털 세대', ‘2635세대' 등을 조명한 세대 분석 리포트에 이어 올 상반기에는 스포츠 소
비자를 주제로 한 '스포슈머' 분석 보고서를 발 간하였다. 이들 보고서는 소비자 조사를 통해 새로운 전반적인 트렌드를 제시한다. 클라이언 트 기업들에게 제품 개발과 커뮤니케이션 시 어떻게 신트렌드를 반영할 수 있을지에 대한 유용한 시사점을 제공할 수 있다.

\section{2 크리에이티브 전략}

광고의 크리에이티브는 브랜드 가치를 높여주 는 전략을 소비자가 이해할 수 있도록 매체상 에서 가시화해내는 것이며, 소비자의 마인드에 경쟁 기업과의 차별화된 포지셔닝이 각인될 수 있게 하는 독특하고 차별적인 아트워크를 창조 해 내는 작업이다. 소비자 심리에 대한 심층 이 해를 근거로 브랜드 전략을 수립하고 브랜드 컨셉을 반영한 광고 작품을 만들어 내는 과정 으로, 제작시 예술성과 창의력이 요구되는 단계 라 하겠다. 제일기획에서는 한국 시장과 소비자 를 움직인 수많은 히트 캠페인을 창출한 바 있 다. 그 예로는 삼성전자와 삼성생명 기업 $\mathrm{PR}$, KTF 'Have A Good Time' 캠페인, KT 메가 패스, 오리온 초코파이, 제일제당 다시다, 동서 식품 맥심, 서울우유, 삼양라면, 에쓰오일 등의 캠페인이 있으며, 이러한 크리에이티브 파워는 국내의 각종 광고대상 수상은 물론, 해외광고제 에서도 국내 최초 클리오(Clio) 파이날리스트 진출, 칸느(Cannes) 금사자상 수상 등의 화려 한 성과로 이어졌다.

제일기획에서는 크리에이티브에서 경쟁 우위 차별화를 꾀하기 위해 크리에이티브 디렉터 중 심의 광고주 전담 조직을 운용한다. 국내외를 가리지 않고 능력있는 크리에이티브 디렉터를 
고용하고 각 크리에이티브 그룹별로 제작하는 조직 시스템을 갖추고 있다.

최근에는 30 초 $\mathrm{TV}$ 광고나 기타 일반적인 매 체 광고가 아닌 새로운 형식의 온라인 광고를 사용하여 광고계와 소비자들에게 큰 반향을 불 러일으킨 바 있다. 2005년 제일기획은 "애니모 션” “애니클럽” 등 7 분 분량의 뮤직 비디오 형 식 애니콜 광고를 국내 최초로 선보였다. 이러 한 뮤직 비디오 형식의 광고는 인터넷 상으로 도 배포되었고, 네티즌들의 입소문을 통해 빠르 게 확산되었다. 기존의 광고가 광고기획사/기업 이 소비자에게 일방적으로 배포하는 일방향 커 뮤니케이션의 형태의 광고였다면 “애니모션”과 “애니클럽”은 단순한 광고로서의 역할 뿐 아니 라 젊은 층의 호응을 받는 가수의 작품 형태인 엔터테인먼트형 광고(advertainment)와 OSMU (one source multi-use)의 신세대형 크리에이티 브 전략을 구사한 것으로 평가된다.
3.3 미디어 전략

최근 소비자들의 미디어 사용 현황을 보면 크 게 공중파 $\mathrm{TV}$ 의 시청률이 10 년 전에 비해 $20 \%$ 이상 저하되고, 소위 ‘뉴미디어’라고 불리는 디지털케이블, 위성 TV, 인터넷, 모바일 통신 등 은 빠르게 성장하고 있다. <표 3>을 보면 제일 기획의 전파 매체 구매가 2004년 대비 2005년 에 크게 감소하고, 대신 인쇄 매체와 BTL 매 체(below the line media, 인터넷, 프로모션 등) 의 사용이 증가하는 경향을 관찰할 수 있다. 제 일기획에서는1999년부터는 인터넷 사업을 매체 부분으로 조직화하고 관련 사업을 과학화하는 데 힘쓰게 된다.

이처럼 미디어 환경과 소비자는 급변하고 있 으므로 각 클라이언트에게 가장 활용도가 높은 매체 사용을 제안하기 위해서는 타겟 소비자의 미디어 사용 현황에 대한 과학적인 조사가 선 행되어야 한다. 이에 부응하는 제일기획의 미디 어 전략의 특징은 수량 모델에 근거한 과학적

<표 3> 2005년 제일기획의 매체구매 현황

2005 BILLINGS BREAKDOWN

단위: 억원

\begin{tabular}{|lrrc|}
\hline & 2004 & 2005 & 신장률(\%) \\
\hline 전파 & 7,184 & 6,353 & -11.6 \\
\hline 인쇄 & 2,914 & 3,376 & 15.9 \\
\hline 소계 & 10,098 & 9,729 & -3.7 \\
\hline 제작 & 865 & 1,190 & 37.6 \\
\hline 프로모션 & 4,211 & 4,865 & 15.5 \\
\hline 인터넷 & 408 & 427 & 4.7 \\
\hline 소계 & $\mathbf{5 , 4 8 4}$ & $\mathbf{6 , 4 8 2}$ & $\mathbf{1 8 . 2}$ \\
\hline 기타 & 718 & 752 & 4.7 \\
\hline 총계 & $\mathbf{1 6 , 3 0 0}$ & $\mathbf{1 6 , 9 6 3}$ & 4.1 \\
\hline
\end{tabular}




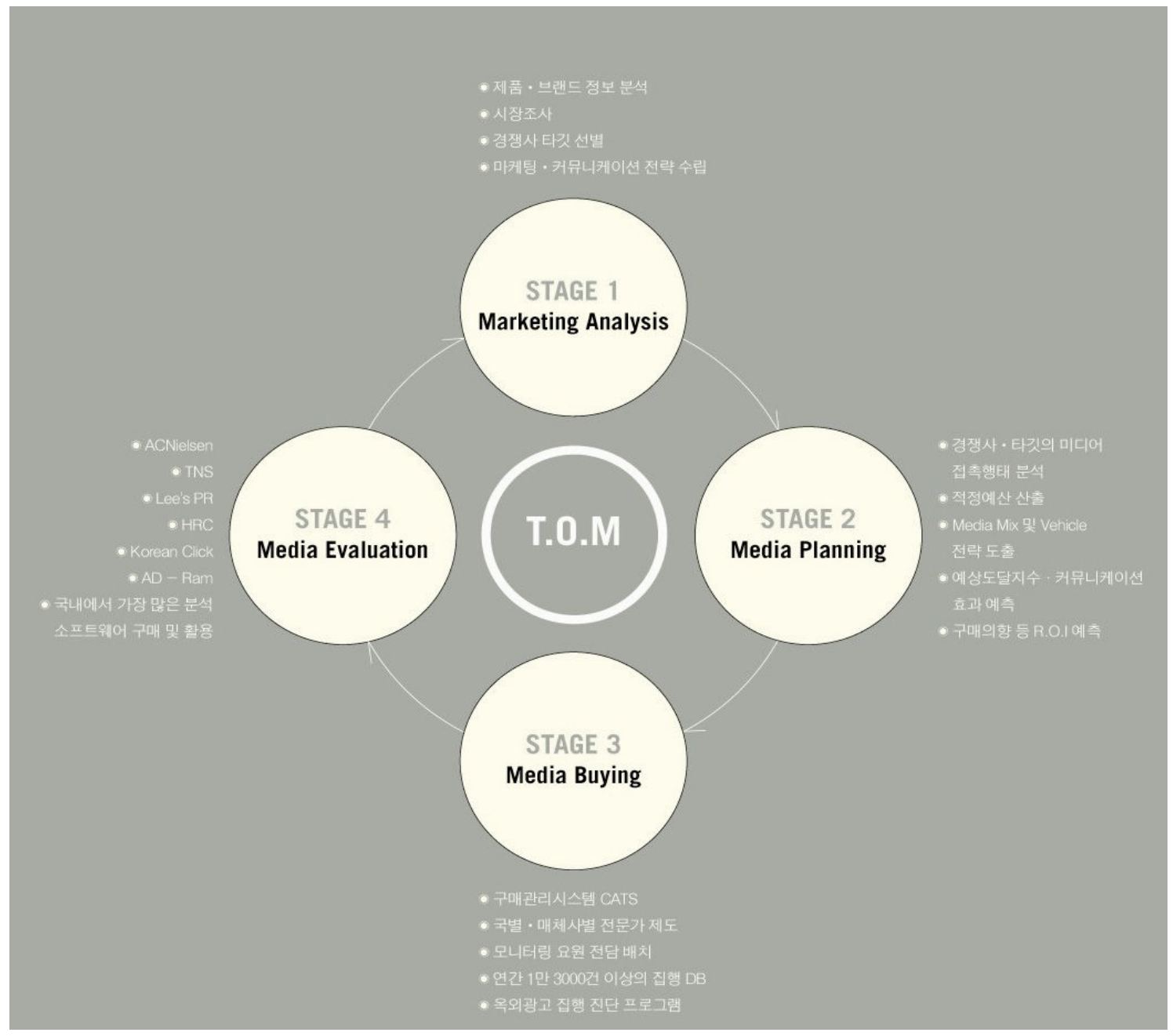

인 매체 전략 수립과 시행이다.

제일기획은 광고주의 고민과 과제에 부응하기 위해 동반자적 입장을 표명하는 "Win Together, TOM Process"(고객의 top of mind, 매체의 top of media)를 슬로건으로 하는 매체의 다양
화, 통합적 마케팅 커뮤니케이션을 추구한다.

$<$ 그림 $4>$ 에서 보여지듯이 제일기획의 매체 전 략은 실증적 소비자 조사를 근간으로 한 마케 팅 전략에 기초하여 이루어진다.

또한 자체 개발 미디어 전략 모델인 C-Map

2) 미디어 분석과 광고 예산(ad budget) 책정 시에도 브랜드 광고 목표를 미리 (1) 시장점유율-광고점유율 달성법 (market share-share of voice objective), (2) 커뮤니케이션 목표 달성법 (communication objective), (3) 유효도달율 달성법 (effective reach objective)등 다각적으로 수립해 보고 각각의 목표를 달성하기 위한 예산을 미리 계산하여 광고주에게 보다 정확한 목표 설정에 근거한 예산 사용의 선택 사항을 제시할 수 있게 하였다. 
을 이용하여 광고 커뮤니케이션 효과와 마케팅 효과를 미리 예측할 수 있고, 이에 따라 미디어 플래닝, 예산 설정이 이루어지게 된다. 기획 단 계에서는 미디어 타겟 분석, 경쟁사 분석, 광고 예측 효과와 적정 광고비 산출이, 실행 단계에 서는 미디어 확보와 관리, 시장 소비자 노출 확 인, 집행 결과의 보고가, 그리고 마지막 평가 단계에서는 광고 효과 및 집행 상황을 측정하 여 차후 플래닝에 반영하게 된다. ${ }^{2)} 1990$ 년대에 들어서 구매관리 자동화 시스템CATS (Cheil Advanced Traffic System)을 구축하여 매체 관리 전 과정을 모니터할 수 있게 되었다.

특히 자체 미디어 관련 R\&D 역량을 강화하 기 위해 미디어 전략 연구소를 2002년 발족하 고, 통계학 및 석사 이상의 인력을 전담 배치하 였다. 국내 유수 대학과 산학 협동 프로젝트를 수행하고, 판매 예측(sales forecast)모델, 매체 별(옥외광고, 케이블 $\mathrm{TV}$, 인터넷 등) 광고 효 과 평가 모델을 개발하는 등 연구 개발에 주력 하였다. 내부 (in-house) 미디어 전략 연구소에 서는 소비자의 미디어 사용과 라이프스타일의 관계를 정량적 정성적으로 분석한다. 첫번째 정 량적 분석 단계에서는(quantitative analysis phase) 소비자가 하루 중 언제, 어떤 활동을 하 며 어떤 미디어를 사용하는지 계량적으로 분석 한다. 예를 들어 아파트 업종의 클라이언트인 건설회사를 위해서 주부 타겟(target)의 주요 미디어 이용, 접촉 시점을 조사한 결과, 접촉 시점은 집안 휴식와 가사 활동이며 대부분 주 부들이 동시에 한 개 이상의 미디어를 접촉하 는 것으로 나타났다. 주부들의 미디어 동시 사 용률이 높다는 것은 미디어 간 간섭, 방해 요소 가 많아 광고 효과가 낮아질 수 있다는 것을
의미하므로 주요 미디어 선별 및 특히 몰입도 가 높은 컨텐츠를 활용한 광고 집행을 제안하 였다. 한편 휴대폰 업종 타겟 소비자의 주요 활 동별 미디어 접촉 현황을 분석한 결과, 집안 휴 식 시 미디어 접촉은 주중과 주말의 차이가 크 지 않으나, 외출과 야외 활동의 경우 주중보다 주말의 접촉량이 3 배 이상 증가하므로 20 대를 겨냥한 휴대폰 업종의 옥외 교통 광고는 주말 활동을 고려한 동선으로 집행하는 것이 효과적 임을 제안하였다.

두번째 정성적 분석 단계(qualitative analysis phase)에서는 광고 효과가 높은 일상 활동과 미디어를 계량적으로 분석하여 목표 타겟 소비 자에 대한 효과적인 커뮤니케이션 접점과 시점 을 선별할 수 있게 한다. 예를 들어 오전 시간 의 TV와 저녁 시간의 $\mathrm{TV}$ 의 광고 효과를 비교 하거나, 잡지와 극장의 광고 효과 차이를 비교 할 수 있는데, 종합적인 질적 효과 분석으로 미 디어 접촉시 소비자의 몰입 정도와 광고 메시 지에 대한 수용 태도를 이용한 4분면 매트릭스 분석으로 보다 구체적인 미디어 전략을 수립할 수 있게 하였다.

\section{4 성공 전략 적용 사례}

본 절에서는 제일기획에서 삼성전자 애니콜의 브랜드 자산을 성공적으로 관리한 사례를 소개 하고자 한다. Interbrand에 의하면 삼성전자는 1990년 중반에는 경쟁사인 모토롤라, 노키아, 파나소닉, 노키아 등에 비교하여 브랜드 자산이 매우 미약하였으나, 지속적인 브랜드 구축과 노 력을 기울이고 혁신적인 프리미엄 브랜드로서 발전시키기 위해 핵심 제품인 휴대폰과 고급 
$\mathrm{TV}$ 에 선택적으로 집중한 결과, 현재는 SONY 브랜드에 필적하는 혹은 이를 능가하는 브랜드 자산을 가지게 된 것으로 평가되고 있다. 삼성 전자의 브랜드 자산은 약 1 억 2천 6 백만불 이 상으로 평가되며, 전 세계 상위 100 위 브랜드 중 하나로까지 급성장하였다(Interbrand 2005).

그러나 1990년 초 한국의 휴대폰 시장은 모토 롤라가 시장의 $80 \%$ 이상을 차지하는 독점 시장 이었고, 삼성전자가 출시한 휴대폰은 국내 시장 에서 고전을 면치 못하고 있었다. 제일기획의 클라이언트인 삼성전자는 1993년 이건희 회장 의 "마누라와 자식 빼고는 모든 것을 다 바꾸 어라”는 신경영 선언의 기치 아래 이미 생산되 어 있던 삼성 휴대폰 200 억원 가량의 물량의 공개 휴대폰 화형식을 거행하는 결의를 보였다. 즉 양적 성장의 한계점에 도달한 삼성이 세계 로 뻗어나가기 위해서는 질적 성장을 통해 세 계 최고급의 제품을 생산할 수 있어야 한다는 기업주의 비전이 이처럼 절실하게 표현된 것이 었다. 더불어 삼성전자의 광고 대행사인 제일기 획에게는 어떻게 해야 삼성휴대폰을 세계적인 브랜드로 발전시킬 수 있는가 하는 브랜드 육 성과제가 주어졌다.

우선 제일기획에서 실시한 B-Master 전략의 첫번째 단계인 브랜드 평가와 진단 소비자 조 사에서 소비자들은 휴대폰 브랜드의 성과 평가시 브랜드의 상징적 이미지(symbolic image, $45.8 \%$ ), 인지(awareness, $42.3 \%$ ), 기능성 (functionality, $11.9 \%$ ) 등의 순서로 중요성을 가지는 것으로 밝혀졌다. '삼성전자'가 주는 기능적이고 신뢰성
있는 이미지를 잃지 않으면서도 보다 즐겁고 활동적이고 젊은 이미지를 강조한 '애니콜' 브 랜드를 분리해 냄으로써 소비자들의 심층 심리 의 섬세한 요구에 부응하는 브랜드 컨셉을 설 정해 낸 것이다. ${ }^{3)}$

타 경쟁 휴대폰 브랜드와의 매트릭스 비교 분 석 결과 애니콜은 기능성에서는 타의 추종을 불허하는 경쟁 우위를 가졌지만 상징적 이미지 면에서는 타 브랜드보다 월등하게 뛰어나지는 않은 것으로 밝혀져, 전반적 이미지 제고 작업 이 필요하다고 판단되었다. 또한 포지셔닝 맵 (positioning map)분석 결과 유행 선도력과 무 선 인터넷 사용 측면에서 경쟁 브랜드들이 이 미 애니콜을 빠르게 추격하고 있어, 이에 대한 대책 마련의 필요성이 제기 되었다.

애니콜 브랜드 가치를 제고하기 위한 세 가지 방안이 제시되었는데 첫째는 애니콜의 상징적 이미지 강화가 필요하다는 점, 둘째는 애니콜의 상징적 이미지 강화는 애니콜이 이미 선점하고 있는 기능적 우위성을 바탕으로 진행되는 것이 바람직하다는 점, 셋째는 무선 초고속 인터넷을 사용한 '내 손안의 디지털 세상' 이미지를 구축 하는 것이 필요하다는 점이었다.

다음 단계로는 브랜드 아이덴티티 작업이 진 행되었다. 애니콜은 1993년 브랜드 런칭시 '언 제 어디서나 통화가 가능하다'는 컨셉으로 시작 되어 1998년 '언제 어디서나 한국인은 애니콜', 1999년 '내 손 안에 더 큰 세상'으로 이어졌고, 연계하여 2000년 '내 손 안의 디지털 세상'이라 는 컨셉으로 발전되었다. 이후 보다 즐겁고 활

3) 초창기1993년에는 '삼성 휴대폰'으로서 기업명을 마스터 브랜드로 사용되어 왔으나, 1994년부터는 '애니콜'이라는 하부 브 랜드가 수립되었고, 이후 '삼성 애니콜'로 혼용 사용되다가, 1997년부터 삼성을 뗀 '애니콜'을 마스터 브랜드로, '삼성'을 후원 브랜드로 전환하게 된다. 
동적인 젊은 이미지를 강조한 '디지털 익사이 팅'이 2001년 애니콜의 브랜드 컨셉으로 수립되 었다.

제일기획에서 제작한 '한국지형에 강하다' (1995년), '언제 어디서나 한국인은 애니콜' (1998년), '내 손안의 큰 세상'(1999년)으로부터 ‘디지털 익사이팅'(2001년) 캠페인을 실행한 결 과, 애니콜 브랜드는 브랜드 로열티, 지각된 가 치, 구입 의향을 합산한 브랜드 성과 지표 (brand performance index: BPI)에서 모두 경 쟁 브랜드보다 매우 월등한 위치를 점한 것으 로 나타났다(<그림 $5>$ 참조). 제일기획에서 애 니콜의 브랜드 가치를 높이는 통합적 브랜드 자산 관리 서비스를 B-Master시스템을 통해 제공한 성공 사례이다.

애니콜 외에도 공격적인 스포츠 마케팅 전략 으로 브랜드 가치를 높인 사례가 있다. 제일기 획이 펼친 삼성전자 글로벌 마케팅은 1996년 아틀란타 올림픽에서부터 시작되었다. 당시 올
림픽 개최지인 아틀란타 시내 다운타운에 삼성 홍보관을 설치하고 공간 스페이스 디자인, 옥외 광고를 자체적으로 실시한 것이 제일기획의 본 격적인 해외 진출의 시작점이라 할 수 있다. 사 후 광고 효과 조사를 통해 이 독자적인 홍보 캠페인의 성공을 확인할 수 있었고, 이 경험이 제일기획으로 하여금 '우리도 세계 시장에서 해 낼 수 있다'는 자신감을 내부적으로 다지게 된 계기가 되었다. 이후 1997년 삼성전자가 나가노 올림픽 공식 스폰서쉽을 $\mathrm{IOC}$ 와 체결하게 됨에 따라 이 모든 작업을 총괄하는 업무를 맡게 되 었고, 계속적으로 1999년 동계 아시아 게임 개폐회식, 2000 시드니 올림픽, 2002년 한-일 월 드컵 개막식 행사 등 국제 스포츠 관련 홍보 업무를 수주 받아 국내외 시장의 4 대 매체 광 고와 홍보관, 호스피탤리티(hospitality) 프로그 램. 관련 이벤트 전개 등을 성공적으로 수행하 면서 해외무대에서의 스포츠 마케팅 역량을 강 화하여 왔다.

<그림 5> 삼성 애니콜과 타 휴대폰 브랜드간의 브랜드 성과 비교

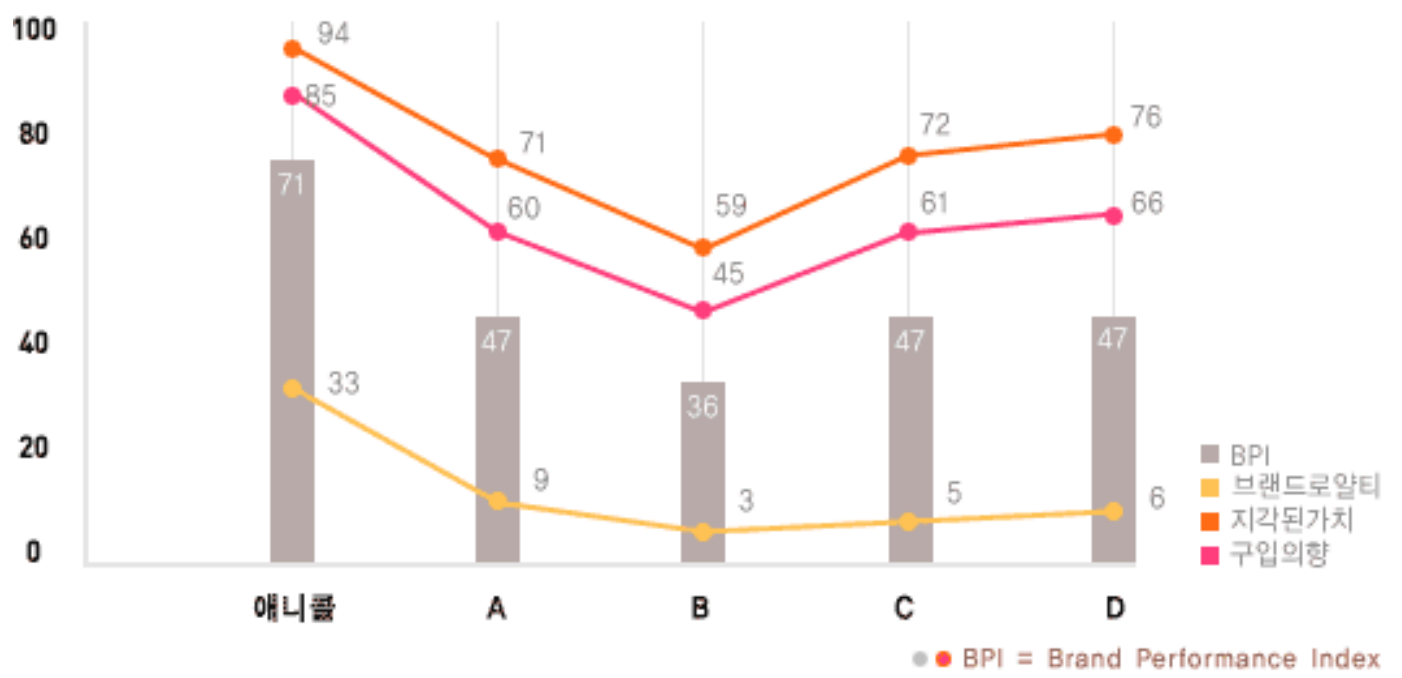


2004년 아테네 올림픽에서는 무선 통신 부문 의 공식 파트너인 삼성전자의 홍보 마케팅 대 행을 맡아, 올림픽 최초의 전 세계 성황 봉송 릴레이를 필두로 그리스 현지에서의 삼성전자 홍보관 운영, 호스피탤리티(hospitality) 프로그 램 등 광고와 홍보(public relations), 이벤트와 전방위 마케팅 활동을 통해 삼성전자의 브랜드 가치와 광고주 만족도를 크게 향상시켰다. 아울 러 삼성전자 글로벌 마케팅의 일환으로 영국의 명문 축구 클럽인 첼시(Chelsea) 구단에 대한 공식 후원 및 미국 미식축구리그 (National Football League: NFL)와의 스폰서쉽 체결을 성공적으로 수행하여 클라이언트 브랜드의 국 제적 인지도를 높이는 데 크게 기여하였다.

\section{IV. 향후 과제}

앞에서 살펴본 바와 같이, 제일기획은 과학적 인 소비자 조사를 바탕으로 한 브랜드 가치의 제고 전략, 창의적 완성도를 극대화하는 크리에 이티브 전략, 그리고 정량적·정성적 소비자 조 사를 바탕으로 한 과학적 미디어 전략을 통해 클라이언트 기업의 브랜드 파워를 향상시키고, 광고주와 소비자의 만족을 극대화시키기는 데 지속적인 노력을 기울여 왔다.

지금까지 제일기획은 클라이언트 기업인 삼성 전자가 글로벌 브랜드로 성장하는 과정에서 그 마케팅 캠페인의 견인차적 역할을 하며 글로벌 대행사로서의 위상을 높여왔다. 현재 제일기획 의 글로벌 조직을 살펴보면 미국, 멕시코, 브라 질, 영국, 독일, 러시아, 중동 및 아시아 등 전
세계 각 지역에 지역별 법인과 사무소를 수립 하여 각국에서 선진화된 지역 마케팅(regional marketing)을 수행해 나가고 있다. 특히 2005년 에는 러시아 법인과 우크라이나 법인에 소비자 조사 $\mathrm{ACR}$ 시스템을 개설하고, 지역 거점의 경 쟁력 강화에 주력하면서 전략 국가에 대한 지 역별 일등화 전략을 수립하는 등 글로벌 기업 으로의 변모를 꾀하고 있는 중이다. 향후 제일 기획의 과제는 국내외 클라이언트 베이스를 다 각화시키는 것이며, 보다 독립적인 글로벌 에이 전시로 발전해 나가기 위한 지속적인 노력이 필요하다.

웰빙과 스포츠에 대한 소비자 관심이 증가하 고 소비자의 가치관과 행동, 트렌드도 끊임없이 변화하고 있다. 세계 경제는 유가 급등과 원자 재 가격 상승, 정치적 불안 요소의 혼재와 테러 위협으로 위축되고 있고, 국내 경제 또한 내수 부진과 경기 침체 양상을 띠고 있다. 광고계 역 시 사회와 기술의 변화에 맞춰 끊임없이 변하 고 있다. 근래에 케이블 TV, 인터넷, 모바일, $\mathrm{DMB}$ 등 뉴미디어가 두각을 나타내고 있고, 최 근에는 싸이, 블로그 등 1 인 미디어가 각광을 받는 등 미디어 환경의 변화가 가속화되고 있 으며, 국내 유수의 광고대행사들이 다국적 기업 으로 편입되는 등 광고계는 계속적으로 무한 글로벌 경쟁 체제로 개편되고 있다. 국내외 경 계 없이 전개되는 글로벌 무한 경쟁 시대에 제 일기획이 글로벌 경쟁력 확보라는 큰 흐름을 일관성 있게 유지해 나가기 위한 끊임없는 자 기 재창조가 필요하다. 제일기획은 현재 국내 1 위의 자리에 안주하지 않고 세계 1 위로 성장해 나가기 위해 2010년까지 20개 이상의 해외 법 인을 확보하고 독자적으로 광고 대행을 할 수 
있는 글로벌 에이전시로 성장하고자 하는 목표

를 설정하였다. 급변하는 환경 변화에 대응하는 다각적인 브랜드 전략의 수립과 창의적인 크리 에이티브의 개발을 통해 클라이언트의 브랜드 가치를 극대화시키는 제일기획의 세계속으로의 행보가 더욱 기대된다.

<논문 접수일: 2006. 09. 30> <게재 확정일: 2006. 09. 30>

\section{참고문헌}

하영원, 전성률, 김익태, 김기수, 홍성민 (2003), "Brand Value-Up: 브랜드 진단 및 관리 모 형 정립을 위한 시도," 한국마케팅저널, 5 (4), 48-71.

Aaker, David A. (1991), Managing Brand Equity: Capitalizing on the Value of Brand Name. New York: Free Press.

Interbrand (2005), “The World's Most Valuable

Brands 2005, "Interbrand Annual Survey.

* 본 사례에 소개된 제일기획의 전략, 브랜드 모 델, 미디어 조사 방법, 성공 전략 적용 사례 등은 제일기획 사보, 웹사이트, 기타 사내 자 료, 담당자와의 인터뷰 자료에 근거하였음을 밝힙니다. 


\title{
Cheil Communications: Empowering Brands with Total Strategic Planning and Creative Media Solutions
}

\author{
Eun-Ju Lee* \\ Chang Jo Yoo** \\ Sang Lin Han***
}

\begin{abstract}
Cheil Communications, a leading ad agency in Korea. has been implementing successful marketing strategies in the following three areas: (1) total strategic planning that maximizes clients' brand equity; (2) distinctive creative strategies that increase viewer acceptance with outstanding artwork; and (3) media planning and execution strategies based on systematic consumer research. This case demonstrates how Cheil Communications has empowered the clients' brands in the ever-changing marketplace, reinventing itself as a prominent global agency for the future.
\end{abstract}

Key words: Cheil communications, total brand management, creative strategy, media strategy, consumer research

* Chung-Ang University

** Dongguk University

*** Hanyang University 